\title{
Current antiangiogenic agents in oncology and ophthalmology
}

\author{
Minireview
}

M. CERNAK ${ }^{1}$, L. NOGOVA ${ }^{2}$

${ }^{1}$ Department of Ophthalmology, University Hospital, Antolska 11, 851 07, Bratislava, Slovakia; ${ }^{2}$ First Department of Internal Medicine, Center for Integrated Oncology, University Hospital Cologne, Kerpenerstr. 62, 50937 Cologne, Germany

${ }^{\star}$ Correspondence: cernakmartin@yahoo.co.uk

Received June 19, 2015 / Accepted August 13, 2015

Antiangiogenic drugs are approved for many cancer types for longer than a decade. Furthermore, several antiangiogenic agents are approved for local application in ophthalmology for treatment of macular degeneration, venous retinal occlusion and diabetic retinopathy. Knowing that antiangiogenic agents are active in ocular system, we reviewed the current literature, whether antiangiogenic drugs may cause ocular side effects in cancer patients by systemic application.

Furthermore, we searched in published papers, if systemic application of antiangiogenic agents in cancer patients may simultaneously treat their ocular disorders, if they have such.

Finally, we emphasized cooperation between an oncologist and ophthalmologist when treating patients with antiangiogenic drugs.

Key words: angiogenesis inhibitors, vascular diseases, eye, drug-related side effects and adverse reactions

In a majority of solid tumors in advanced stages, prognosis after chemotherapy remains poor. Thus, median overall survival after chemotherapy treatment in unselected patients with nonsmall lung cancer is 10 months [1], in patients with colorectal cancer 15.6 months [2] and with breast cancer 15.4 months [3].

In last decades, new treatment approaches have been sought to improve overall survivals of patients with solid tumors. It has been shown that especially inhibition of signal transduction, antiangiogenesis and tumor-immunotherapy led to prolonging of overall survival.

As treatment with inhibitors of signal transduction is beneficial only for small part of patients with defined genetic alterations, treatment with antiangiogenic agents and immunotherapy seems to help a large spectrum of patients with frequent biomarkers.

Immunotherapeutic agents have been approved during last two years and many clinical trials are still running. Median overall survival of several studies has not been reached and also side effects of these drugs are still analysed.

On the other hand, median survival rates and side effects of antiangiogenic drugs are better and longer known due to first approval more than ten years ago. Beside the most frequent side effects of these drugs, such a hypertension, bleeding, thromboembolism, renal impairment and others, little is known about ocular side effects.

Additionally, antiangiogenic drugs are frequently used in treatment of several opthalmological disorders.

In our minireview, we describe current antiangiogenic drugs approved for cancer and opthalmological disorders in Europe. We discuss the ocular side effects of antioangiogenic agents in oncology and summarize the benefits of these drugs in ophthalmology. We have also reviewed literature on ophthalmological benefits by systemic application of antiangiogenic drugs. This approach can be used in cancer patients with ocular problems, if they receive antiangiogenic treatment for their cancer diagnosis.

\section{Antiangiogenic drugs - mechanism of action, approval studies}

The idea of angiogenesis and its role in cancer treatment came in 1971 from Judah Folkman [4], but the first antiang- 
iogenic drug was approved by Food and Drug Administration (FDA) 33 years later after results of a phase III study for colorectal cancer $[2,5]$

In tumor angiogenesis, vascular endothelial factor A (VEGF-A, usually called VEGF) and vascular endothelial growth factor receptor 2 (VEGFR-2) play the key role. The circulating isoforms of VEGF - VEGF ${ }_{121}$ and $\mathrm{VEGF}_{165}$ signal through VEGFR-2 and support developing angiogenesis [5].

First approved antioangiogenic drug was a humanised VEGF antibody bevacizumab in 2004. Currently, bevacizumab is approved in combination with chemotherapy for metastatic stages of colorectal carcinoma, breast, ovarian and non-small cell lung cancer. Furthermore, bevacizumab is approved for patient with metastatic carcinoma of the cervix and in combination with interferon-alfa for advanced renal cell cancer [6].

The approval phase III study in first line metastatic colorectal cancer showed an increase in median overall survival from 15.6 to 20.3 months by adding bevacizumab to standard chemotherapy [2]. In non-small cell lung cancer patients, the gain in median overall survival was 2 months in a phase III study in metastatic patients, if bevacizumab was added to standard chemotherapy (10.3 months in the group without and 12.3 in the group with bevacizumab) [1].

In metastatic breast cancer, adding bevacizumab to chemotherapy in phase III trial showed an increase in progression free survival from 8.0 to 9.2 months comparing to placebo plus chemotherapy [7].

Patients with metastatic renal cell carcinoma benefited from adding bevacizumab to standard treatment (interferon-alfa $2 \mathrm{a}$ ) and showed an increase in median progression free survival from 5.4 (placebo group) to 10.2 months (bevacizumab) [8].

In patients with stage III or IV ovarian cancer, the addition of bevacizumab to standard chemotherapy showed an increase of median progression free survival of about 4 months (from 10.3 months in the control group to 14.1 months in the bevacizumab group) [9].

Bevacizumab in combination with chemotherapy in patients with recurrent, persistent or metastastatic cervical cancer showed a median overall survival of 17 months comparing to 13.3 months in the group without bevacizumab [10].

Sorafenib is an oral multikinase inhibitor with activities against Raf kinase and with inhibition of vascular endothelial growth factor receptors (VEGFRs) $1 / 2 / 3$, platelet-derived growth factor receptor- $\beta$ (PDGFR- $\beta$ ), c-Kit and RET pathways. Inhibition of VEGFR and PDGFR activity by sorafenib contributes to its anti-angiogenic effects [11].

Sorafenib is approved for advanced hepatocellular and renal cancer and for iodine resistant advanced thyroid cancer [12].

The approval study of sorafenib on advanced hepatocellular carcinoma showed a significantly longer median overall survival in the sorafenib than in the placebo group (10.7 versus 7.9 months [13].

In advanced renal cell carcinoma, in the phase III study with sorafenib versus placebo, the median overall was 19.3 months in the sorafenib group and 15.9 months in the placebo group [14].

The recent approval for radioactive-iodine refractory advanced differentiated thyroid cancer is based on the results of the phase III study with sorafenib versus placebo. The median progression free survival was 10.8 versus 5.8 months [15].

Sunitinib is a multikinase inhibitor with an activity against VEGFRs, PDGFRs, the stem cell factor receptor (c-KIT) and the FLT3 and RET kinases [16]. Sunitinib is approved for treatment of advanced renal cell carcinoma, not resectable and/or metastatic gastrointestinal stromal tumor (GIST) and not resectable/metastatic well differentiated pancreatic neuroendocrine tumors (pNET) [17].

In patients with imatinib-resistant advanced GIST, sunitinib showed time to tumor progression of 27.3 weeks comparing to 6.4 weeks in the placebo group [18].

In metastatic renal cell carcinoma, the median progression free survival was 11 months in the sunitinib group comparing to 5 months in the interferon alfa group [19].

In advanced well differentiated pNET, median progression free survival was 11.4 months in the sunitinib group and 5.5 months in the placebo group [20].

Nintedanib is a multikinase inhibitor of VEGFRs, Fibroblast Growth Factor Receptors (FGFRs) and PDGFRs [21]. Nintedanib is approved in combination with docetaxel for advanced adenocarcinoma of the lung after first-line treatment [22]. The approval is based on the results of the phase III study showing an improved median progression free survival of 3.4 months in patients treated with docetaxel and nintedanib comparing to 2.7 months in patients receiving docetaxel plus placebo. The analysis on progression free survival concerns all NSCLC histologies included into the trial. The median overall survival of patients with adenocarcinoma in the nintedanib group was 12.6 months comparing to 10.3 months for adenocarcinoma patients in the placebo group [23].

Pazopanib is a multikinase inhibitor of VEGFRs, PDGFRs, FGFRs and c-KIT. It is approved for treatment of advanced renal cell carcinoma and for several types of second line metastatic soft tissue sarcoma [24].

In patients with metastatic soft tissue sarcoma, the treatment with pazopanib showed a median progression free survival of 4.6 months comparing to 1.6 months with placebo [25].

In advanced renal cell carcinoma, median progression free survival was 9.2 months for pazopanib comparing to 4.2 months in the placebo group [26].

Axitinib is an inhibitor of VEGFRs, PDGFR and c-KIT. It is approved for treatment of metastatic renal cell cancer after first line treatment [27]. The approval study showed a median progression free survival of 6.7 months in axitinib comparing to 4.7 months in sorafenib group [28].

Ramucirumab is a fully human monoclonal antibody with high binding affinity to the extracellular domain of VEGFR-2 [29]. Ramucirumab is approved for treatment of second line advanced gastric cancer [30].. The approval is based on results 
of the phase III study showing an advantage in median overall survival in patients receiving ramucirumab (5.2 months) comparing to placebo (3.8 months) [31].

Aflibercept is a recombinant fusion protein having VEGFbinding part from the extracellular domain of VEGFR-1 and 2, which is fused to the Fc portion of human immunoglobulin IgG. Aflibercept as a ligand trap inhibits VEGF and placental growth factor (PIGF) ligands from binding to their endogenous receptors $[5,32,33]$.

Aflibercept is approved for treatment of second line metastatic colorectal cancer and for treatment of visual impairment due to diabetic complications, treatment of macular oedema and wet macular degeneration $[34,35]$.

In the approval study for colorectal cancer, the median overall survival was improved by adding aflibercept to standard chemotherapy when compares to placebo (13.50 versus 12.06 months) [33].

The approval study of aflibercept in diabetic macular oedema showed significant superiority in functional and anatomic endpoints over laser treatment [36].

\section{Side effects of antiangiogenic agents with focus on ocular toxicity}

Except the serious adverse drug reaction such a haemorrhage, gastrointestinal perforation, arterial and venous thromboembolism, posterior reversible encephalopathy syndrome, the most common side effects of antiangiogenic drugs are hypertension, fatigue or asthenia, diarrhoea, vomiting, abdominal pain, impaired wound healing, proteinuria, hand-foot syndrome and other skin disorders (especially in patients treated with VEGFR inhibitors), and formations of fistulas. The cardiac dysfunction/heart failure and QT prolongation should also be considered especially in patients treated with VEGFR inhibitors. Furthermore, proteinuria or other renal disorders, changes in blood cell count, thyroid dysfunction, hypersensitive and allergic reaction may be seen in patients treated with antiangiogenic drugs, $[6,30,35,12,17,22,24,34]$.

Little is known about ocular side effects of these drugs. Antiangiogenic drugs are used locally - intravitreal - in treatment of ocular disorders since several years. Thus, they may affect eye function and structure by systemic application. However, it seems that systemic application is associated with some, but minimal risk of ocular toxicity [37-39].

Mild side effects in terms of increased lacrimation by bevacizumab, blurred vision or eyelash discolouration by pazopanib have been seen in some clinical trial with these drugs [6], [24].

A case of neurosensory retinal detachment has been seen in patient with metastatic renal cell carcinoma treated with sunitinib. The patient reported decreased visual acuity in both eyes. Optical coherence tomography (OCT) revealed neurosensory retinal detachment and diffuse oedema in both eyes. The treatment with sunitinib was discontinued. Two weeks later, the OCT showed a complete bilateral resolution of the neurosensory retinal detachment and retinal oedema $[37,40]$. Similar case of retinal detachment and retinal tear was seen in patient treated with pazopanib [24].

Although antiangiogenic drugs do not seem to affect the eye structure directly, a caution should be related to common side effects, which may lead to ocular toxicity [37].

Systemic hypertension, a common side effect of antiangiogenic agents may cause a hypertensive retinopathy [41]. Furthermore, systemic hypertension may increase a risk of other ocular complications such as retinal emboli, retinal arterial and venous onclusion and optic neuropathy [41]. Thromboembolism is a common side effect of antiangiogenic drugs, so a possible synergistic effect should be consider by patients complaining about vision disturbances [37].

Beside that, arterial and venous thromboembolic events in patients treated with antiangiogenic agents may lead to cerebral vascular accidents with interrupted vascular supply of the visual pathway and cortex [37]. Posterior reversible encephalopathy syndrome (PRES) was also reported by treatment with bevacizumab and some VEGFR inhibitors [4243]. Except der neurologic symptoms (headache, confusion, seizures, etc), PRES usually presents with visual disturbances such a blurred vision or visual loss.

Therefore patients, who developed visual disturbances during systemic treatment with antiangiogenic drugs should immediately interrupt their treatment with these agents and promptly assessed by ophthalmologist and neurologist [37].

\section{Use of antiangiogenic drugs in ophthalmology}

The principle of treatment with antiangiogenic drugs in ophthalmology is a blockade of an inappropriate neovascularization. The neovascularization causes a leakage and subsequently lost of vision in an affected eye [44].

Comparing to a systemic treatment with antiangiogenic agents in oncology, ophthalmological patients are treated with antiangiogenic drugs locally. Intravitreal application with antiangiogenic drugs is frequently used by treatment of diabetic retinopathy, age-related macular degeneration, retinopathy of prematurity and retinal vein occlusion (RVO) complications [45-48], (Fig.1,2).

Drugs approved for ophthalmologic indications are ranibizumab (Fab-fragment of monoclonal humanized antibody) and aflibercept (a fusion protein from extracellular fragments of human VEGFR and Fc fragment of human IgG1) [35-49].

Bevacizumab is frequently used in an off-label setting. According to the several studies and a meta-analysis, there should be no difference in efficacy and safety between systemic and intravitreal application $[46,50]$.

However, intravitreal application is preffered route due to potential risks associated with systemic anti-VEGF therapy and the perception that intravitreal therapy is safer [51].

On the other hand, an intravitreal application has an increased risk of ocular inflammation and the side effects in 

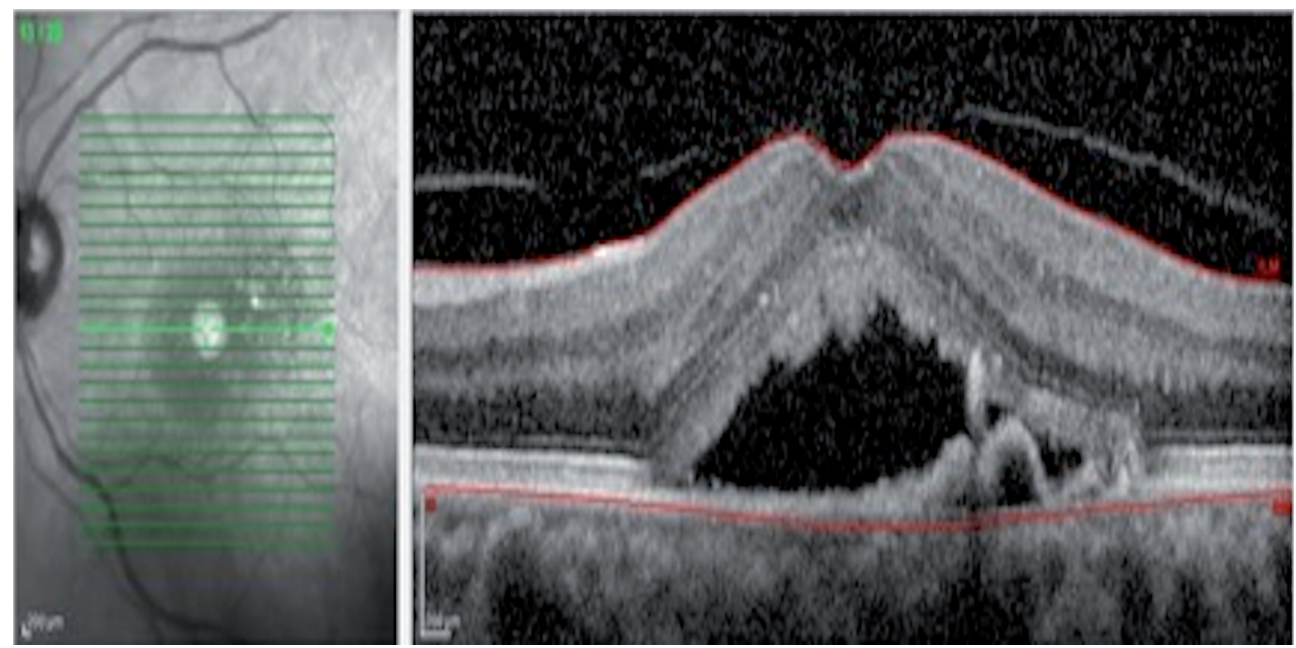

Figure 1. Fundus of the Eye: Exudative age related macular degeneration before treatment
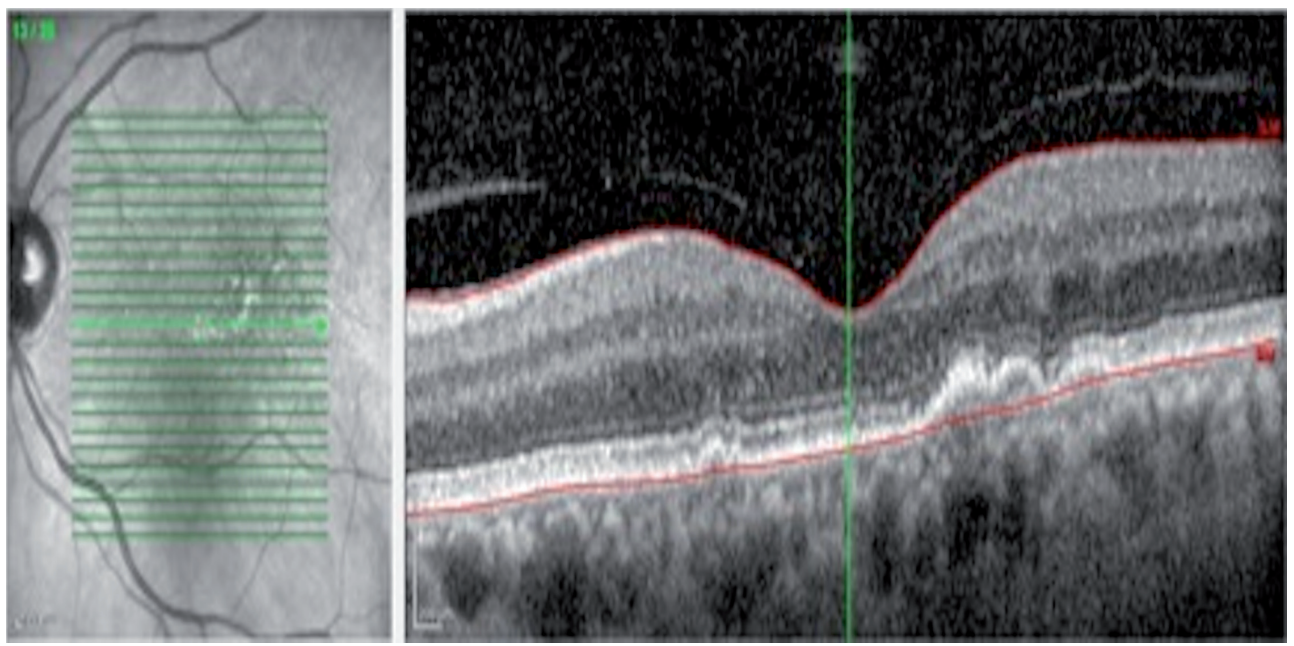

Figure 2. Fundus of the Eye: Exudative age related macular degeneration after treatment with intravitreal injection of Bevacizumab

treatment of premature infants has not been fully investigated yet [52-55].

\section{Systemic treatment of ocular disorders with antiangiogenic agents. A possible double benefit in cancer patients?}

Systemic treatment of ocular disorders with antiangiogenic agents remains surely an option, if this treatment offers more benefits than risks.

Michels et al. investigated 9 patients treated with systemic bevacizumab by age-related macular degeneration. Except a mild elevation of a mean blood pressure, there were no serious systemic or ocular adverse events. A significant increase in visual acuity has been seen 1 week after the treatment [56].

Moshfeghi et al. studied 18 patients with age-related macular degeneration, who were treated with bevacizumab intravenously. The patients received $5 \mathrm{mg} / \mathrm{kg}$ bevacizumab at baseline with 1 or 2 additional infusions at 2 -week intervals. Despite the mild elevation of mean blood pressure, there were no other additional adverse events related to bevacizumab. The treatment was effective for all 18 patients. By six months, most patients did not require any additional treatment beyond the 2 or 3 infusions [51].

Schmid-Kubista et al evaluated 16 eyes treated with either with systemic bevacizumab or placebo. Throughout the 24 weeks follow-up, the lesion size and macular sickness decreased in bevacizumab group significantly [57].

Shouten et al. pooled results of 26 studies on bevacizmab in a systemic review. Particularly, he compared intravenously and intravitreal given bevacizumab. After intravenous application, the mean change in visual acuity was +12.8 ETDRS eye chart letters and the mean change for central retinal thickness 
$-129 \mu \mathrm{m}$. In studies with intravitreal application, the change in visual acuity was +8.6 letters and the change in mean central retinal thickness was $-90 \mu \mathrm{m}[58]$.

Thus, the systemic application of bevacizumab seems to have at least the same clinical benefit as the intravitreal application. Cancer patients with age-related macular degeneration or diabetic retinopathy may surely benefit from systemic bevacizumab treatment, if this is indicated for their oncological diagnosis.

Vice versa, patients with ocular disorders could benefit from systemic administration of bevacizumab, if there are risk factors for intravitreal application, or if they prefer the systemic application. In some studies, systemic bevacizumab application showed even more benefits than local application for ophthalmological patients [58]. However, ophthalmologists are cautious about giving bevacizumab systemic due to potential systemic side effects (hypertension, bleeding, thromboembolism, etc).

\section{Treatment of ocular disorders with VEGFR inhibitors}

Having a successful treatment of ocular disorders with VEGF antibobodies and ligand trap, the question arises, how successful might be the treatment of these diseases with systemic VEGFR inhibitors.

Indeed, some data exist, that this treatment might have a benefit in ocular diseases treated otherwise with VEGF antibodies or ligand trap.

Kernt et al. showed some preclinical data on cell cultures incubated with sorafenib indicating that treatment of age related macular degeneration with sorafenib might be beneficial for affected patients [59]. Furthermore, preclinical data investigated intravitreal injection of sorafenib in a rat model of oxygen induced retinopathy showed an ability of sorafenib to inhibit the retinal neovascularisation in a dose dependent manner [60].

Preclinical mouse model with peroral axitinib showed an effective inhibition of progression of choroidal neovascularisation, so that authors suggested axitinib as a potential therapeutic alternative for age-related macular degeneration [61].

However, there are still little clinical data on use of VEGFR inhibitors in patients with ophthalmological disorders. Clinical trials are desperately needed for further evaluation.

\section{Treatment of ocular disorders with autologous serum eye drops in cancer patients}

For practical reasons we would also like to mention a treatment with autologous serum eye drops especially in cancer patients treated with bone marrow transplantation.

Similar to tears, human serum contains immunoglobulins, vitamin A, fibronectin and growth factors [62].

Dry eye disease associated with Sjögren syndrome in cancer patients after autologous bone marrow transplantation has a known inflammatory component. The growth factors in serum tears help reduce the inflammation, which is reflected in increased tear production and increased Schirmer's scores.

A recently published study investigating 123 patients included also 11 patients with dry eye disorders associated with Graft versus Host disease. The authors used 50\% autologous serum eye drops (serum diluted with $0.9 \%$ sodium chloride). The Schirmer score was still improved at the last follow up visit (average 12 months, range 3 to 48 months).

Thus, $50 \%$ autologous serum eye drops seem to be an effective for long-term treatment of dry eye disease in cancer patients after bone marrow transplantation. They are a valuable option in patients with severe dry disease who have exhausted conventional forms of treatment options [63].

\section{Conclusion}

Several types of antiangiogenic drugs have been well established in treatment of many cancer diagnoses since the last decade. Additionally, two antiangiogenic drugs are approved for local treatment in ophthalmology. Furthermore, the antioangiogenic treatment is still developing in both medical fields - in oncology as well in ophthalmology. It has been shown that systemic treatment of ocular disorders such as age-related macular degeneration revealed at least the same benefits as intravitreal application. This might be considered by treatment of cancer patients having macular changes by choosing the optimal treatment. Furthermore, there are some preclinical data indicating that systemic treatment with VEGFR inhibitors in peroral form may bring benefits in treatment of ophthalmological disorders.

Concerning the ocular side effects of antiangiogenic drugs by systemic treatment, they are usually mild and described such a blurred vision or increased lacrimation. However, it must be noted that the common side effects of antiangiogenic drugs such as hypertension or cerebral thromboembolism may present as visual disturbances. Furthermore, an unusual, but serious side effect of antiangiogenic drugs - posterior reversible encephalopathy syndrome (PRES) usually presents with visual disturbances such a blurred vision or visual loss.

Taken together, a close cooperation between an oncologist and ophthalmologist is definitely needed by current use of antiangiogenic drugs. In many cases, an ophthalmological examination may quickly detect possible side effects in cancer patient and vice versa, an examination due to an internist may reveal systemic side effects in ophthalmological patient. Furthermore, this cooperation is getting more and more important as new anticancer drugs (ALK-inhibitors, heat shock protein inhibitors, FGFR inhibitors and others) with potential ocular toxicity are approved or are currently tested in clinical trials.

\section{References}

[1] SANDLER A, GRAY R, PERRY MC, BRAHMER J, SCHILLER JH et al. Paclitaxel-carboplatin alone or with bevacizumab 
for non-small-cell lung cancer. N Engl J Med 2006; 355: 2542-50. http://dx.doi.org/10.1056/NEJMoa061884

[2] HURWITZ H, FEHRENBACHER L, NOVOTNY W, CARTWRIGHT T, HAINSWORTH J et al. Bevacizumab plus irinotecan, fluorouracil, and leucovorin for metastatic colorectal cancer. N. Engl. J. Med. 2004; 350: 2335-42. http:// dx.doi.org/10.1056/NEJMoa032691

[3] JONES SE, ERBAN J, OVERMOYER B, BUDD GT, HUTCHINS L et al. Randomized phase III study of docetaxel compared with paclitaxel in metastatic breast cancer. J. Clin. Oncol. 2005; 23: 5542-51. http://dx.doi.org/10.1200//CO.2005.02.027

[4] FOLKMAN J. Tumor angiogenesis: therapeutic implications. N. Engl. J. Med. 1971; 285: 1182-6. http://dx.doi.org/10.1056/ NEJM197111182852108

[5] KERBEL RS. Tumor angiogenesis. N. Engl. J. Med. 2008; 358: 2039-49. http://dx.doi.org/10.1056/NEJMra0706596

[6] EUROPEAN MEDICINES AGENCY, EDITOR. Avastin Product Information.

[7] ROBERT NJ, DIERAS V, GLASPY J, BRUFSKY AM, BONDARENKO et al. RIBBON-1: randomized, double-blind, placebo-controlled, phase III trial of chemotherapy with or without bevacizumab for first-line treatment of human epidermal growth factor receptor 2-negative, locally recurrent or metastatic breast cancer. J. Clin. Oncol. 2011; 29: 1252-60. http://dx.doi.org/10.1200/JCO.2010.28.0982

[8] ESCUDIER B, PLUZANSKA A, KORALEWSKI P, RAVAUD A, BRACARDA $S$ et al. Bevacizumab plus interferon alfa-2a for treatment of metastatic renal cell carcinoma: a randomised, double-blind phase III trial. Lancet. 2007; 370: 2103-11. http:// dx.doi.org/10.1016/S0140-6736(07)61904-7

[9] BURGER RA, BRADY MF, BOOKMAN MA, FLEMING GF, MONK BJ et al. Incorporation of bevacizumab in the primary treatment of ovarian cancer. N. Engl. J. Med. 2011; 365: 2473-83. http://dx.doi.org/10.1056/NEJMoa1104390

[10] TEWARI KS, SILL MW, LONG HJ, PENSON RT, HUANG $\mathrm{H}$ et al. Improved survival with bevacizumab in advanced cervical cancer. N. Engl. J. Med. 2014; 370: 734-43. http:// dx.doi.org/10.1056/NEJMoa1309748

[11] WILHELM S, CARTER C, LYNCH M, LOWINGER T, DUMAS J et al. Discovery and development of sorafenib: a multikinase inhibitor for treating cancer. Nat Rev Drug Discov. 2006; 5: 835-44. http://dx.doi.org/10.1038/nrd2130

[12] EUROPEAN MEDICINES AGENCY, EDITOR. Nexavar Product Information. European Medicines Agency.

[13] LLOVET JM, RICCI S, MAZZAFERRO V, HILGARD P, GANE E et al. Sorafenib in advanced hepatocellular carcinoma. N. Engl. J. Med. 2008; 359: 378-90. http://dx.doi. org/10.1056/NEJMoa0708857

[14] ESCUDIER B, EISEN T, STADLER WM, SZCZYLIK C, OUDARD $S$ et al. Sorafenib in advanced clear-cell renal-cell carcinoma. N. Engl. J. Med. 2007; 356: 125-34. http://dx.doi. org/10.1056/NEJMoa060655

[15] BROSE MS, NUTTING CM, JARZAB B, ELISEI R, SIENA $S$ ET AL. Sorafenib in radioactive iodine-refractory, locally advanced or metastatic differentiated thyroid cancer: a randomised, double-blind, phase 3 trial. Lancet. 2014; 384: 319-28. http://dx.doi.org/10.1016/S0140-6736(14)60421-9
[16] MENDEL DB, LAIRD AD, XIN X, LOUIE SG, CHRISTENSEN JG et al. In vivo antitumor activity of SU11248, a novel tyrosine kinase inhibitor targeting vascular endothelial growth factor and platelet-derived growth factor receptors: determination of a pharmacokinetic/pharmacodynamic relationship. Clin. Cancer Res. 2003; 9: 327-37.

[17] EUROPEAN MEDICINES AGENCY, EDITOR. Sutent Product Information.

[18] DEMETRI GD, VAN OOSTEROM AT, GARRETT CR, BLACKSTEIN ME, SHAH MH et al. Efficacy and safety of sunitinib in patients with advanced gastrointestinal stromal tumor after failure of imatinib: a randomised controlled trial. Lancet. 2006; 368: 1329-38. http://dx.doi.org/10.1016/S01406736(06)69446-4

[19] MOTZER RJ, HUTSON TE, TOMCZAK P, MICHAELSON MD, BUKOWSKI RM et al. Sunitinib versus interferon alfa in metastatic renal-cell carcinoma. N. Engl. J. Med. 2007 ed. 2007; 356: 115-24.

[20] RAYMOND E, DAHAN L, RAOUL J-L, BANG Y-J, BORBATH I ET AL. Sunitinib malate for the treatment of pancreatic neuroendocrine tumors. N. Engl. J. Med. 2011; 364: 501-13. http://dx.doi.org/10.1056/NEJMoa1003825

[21] HILBERG F, ROTH GJ, KRSSAK M, KAUTSCHITSCH S, SOMMERGRUBER W et al. BIBF 1120: triple angiokinase inhibitor with sustained receptor blockade and good antitumor efficacy. Cancer Res. 2008; 68: 4774-82. http://dx.doi. org/10.1158/0008-5472.CAN-07-6307

[22] EUROPEAN MEDICINES AGENCY, EDITOR. Vargatef Product Information.

[23] RECK M, KAISER R, MELLEMGAARD A, DOUILLARD $\mathrm{J}$-Y, ORLOV $\mathrm{S}$ et al. Docetaxel plus nintedanib versus docetaxel plus placebo in patients with previously treated non-small-cell lung cancer (LUME-Lung 1): a phase 3, double-blind, randomised controlled trial. Lancet Oncol. 2014; 15: 143-55. http://dx.doi.org/10.1016/S1470-2045(13)70586$\underline{2}$

[24] EUROPEAN MEDICINES AGENCY, EDITOR. Votrient Product Information.

[25] VAN DER GRAAF WTA, BLAY J-Y, CHAWLA SP, KIM D-W, BUI-NGUYEN B et al. Pazopanib for metastatic soft-tissue sarcoma (PALETTE): a randomised, double-blind, placebocontrolled phase 3 trial. Lancet. 2012; 379: 1879-86. http:// dx.doi.org/10.1016/S0140-6736(12)60651-5

[26] STERNBERG CN, DAVIS ID, MARDIAK J, SZCZYLIK C, LEE E et al. Pazopanib in locally advanced or metastatic renal cell carcinoma: results of a randomized phase III trial. J. Clin. Oncol. 2010; 28: 1061-8. http://dx.doi.org/10.1200/ LCO.2009.23.9764

[27] ALBIGES L, GIZZI M, CARTON E, ESCUDIER B. Axitinib in metastatic renal cell carcinoma. Expert Rev Anticancer Ther. 2015; 15: 499-507. http://dx.doi.org/10.1586/1473714 $\underline{0.2015 .1033408}$

[28] RINI BI, ESCUDIER B, TOMCZAK P, KAPRIN A, SZCZYLIK $C$ et al. Comparative effectiveness of axitinib versus sorafenib in advanced renal cell carcinoma (AXIS): a randomised phase 3 trial. Lancet. 2011;378: 1931-9. http://dx.doi. org/10.1016/S0140-6736(11)61613-9 
[29] CLARKE JM, HURWITZ HI. Targeted inhibition of VEGF receptor 2: an update on ramucirumab. Expert Opin Biol Ther. 2013; 13: 1187-96. http://dx.doi.org/10.1517/14712598.2013. 810717

[30] EUROPEAN MEDICINES AGENCY, EDITOR. Cyramza Product Information.

[31] FUCHS CS, TOMASEK J, YONG CJ, DUMITRU F, PASSALACQUA R et al. Ramucirumab monotherapy for previously treated advanced gastric or gastro-oesophageal junction adenocarcinoma (REGARD): an international, randomised, multicentre, placebo-controlled, phase 3 trial. Lancet. 2014; 383: 31-9. http://dx.doi.org/10.1016/S0140-6736(13)61719-5

[32] HOLASH J, DAVIS S, PAPADOPOULOS N, CROLL SD, HO L et al. VEGF-Trap: a VEGF blocker with potent antitumor effects. Proc. Natl. Acad. Sci. U.S.A. 2002; 99: 11393-8. http:// dx.doi.org/10.1073/pnas.172398299

[33] VAN CUTSEM E, TABERNERO J, LAKOMY R, PRENEN H, PRAUSOVÁ J et al. Addition of aflibercept to fluorouracil, leucovorin, and irinotecan improves survival in a phase III randomized trial in patients with metastatic colorectal cancer previously treated with an oxaliplatin-based regimen. J. Clin. Oncol. 2012; 30: 3499-506. http://dx.doi.org/10.1200/ LCO.2012.42.8201

[34] EUROPEAN MEDICINES AGENCY, EDITOR. ZALTRAP PRODUCT INFORMATION.

[35] EUROPEAN MEDICINES AGENCY, EDITOR. EYLEA PRODUCT INFORMATION.

[36] KOROBELNIK J-F, DO DV, SCHMIDT-ERFURTH U, BOYER DS, HOLZ FG et al. Intravitreal aflibercept for diabetic macular edema. Ophthalmology. 2014; 121: 2247-54. http://dx.doi.org/10.1016/j.ophtha.2014.05.006

[37] RENOUF DJ, VELAZQUEZ-MARTIN JP, SIMPSON R, SIU LL, BEDARD PL. Ocular toxicity of targeted therapies. J. Clin. Oncol. 2012; 30: 3277-86. http://dx.doi.org/10.1200/ JCO.2011.41.5851

[38] EISEN T, STERNBERG CN, ROBERT C, MULDERS P, PYLE L et al. Targeted therapies for renal cell carcinoma: review of adverse event management strategies. J. Natl. Cancer Inst. 2012; 104: 93-113. http://dx.doi.org/10.1093/jnci/djr511

[39] COHEN RB, OUDARD S. Antiangiogenic therapy for advanced renal cell carcinoma: management of treatment-related toxicities. Invest New Drugs. 2012; 30: 2066-79. http://dx.doi. org/10.1007/s10637-012-9796-8

[40] WEGNER A, KHORAMNIA R. Neurosensory retinal detachment due to sunitinib treatment. Eye (Lond). 2011; 25: 1517-8. http://dx.doi.org/10.1038/eye.2011.200

[41] WONG TY, WONG T, MITCHELL P. The eye in hypertension. Lancet. 2007; 369: 425-35. http://dx.doi.org/10.1016/ $\underline{\text { S0140-6736(07)60198-6 }}$

[42] GLUSKER P, RECHT L, LANE B. Reversible posterior leukoencephalopathy syndrome and bevacizumab. N. Engl. J. Med. 2006; 354: 980-2-discussion980-2.

[43] CUMURCIUC R, MARTINEZ-ALMOYNA L, HENRY C, HUSSON H, DE BROUCKER T. Posterior reversible encephalopathy syndrome during sunitinib therapy. Rev. Neurol. (Paris). 2008; 164: 605-7. http://dx.doi.org/10.1016/j. neurol.2008.03.007
[44] VOLZ C, PAULY D. Antibody therapies and their challenges in the treatment of age-related macular degeneration. Eur J Pharm Biopharm. 2015. http://dx.doi.org/10.1016/j. ejpb.2015.02.020

[45] MICHAELIDES M, KAINES A, HAMILTON RD, FRASERBELL S, RAJENDRAM R et al. A prospective randomized trial of intravitreal bevacizumab or laser therapy in the management of diabetic macular edema (BOLT study) 12-month data: report 2. Ophthalmology. 2010; 117: 1078-1086.e2. http://dx.doi.org/10.1016/j.ophtha.2010.03.045

[46] CATT RESEARCH GROUP, MARTIN DF, MAGUIRE MG, YING G-S, GRUNWALD JE et al. Ranibizumab and bevacizumab for neovascular age-related macular degeneration. $\mathrm{N}$. Engl. J. Med. 2011; 364: 1897-908. http://dx.doi.org/10.1056/ NEJMoa1102673

[47] MINTZ-HITTNER HA, KENNEDY KA, CHUANG AZ, BEAT-ROP COOPERATIVE GROUP. EFFICACY of intravitreal bevacizumab for stage 3+ retinopathy of prematurity. N. Engl. J. Med. 2011; 364: 603-15. http://dx.doi.org/10.1056/ NEJMoa1007374

[48] DEMIR M, OBA E, GULKILIK G, ODABASI M, OZDAL E. Intravitreal bevacizumab for macular edema due to branch retinal vein occlusion: 12-month results. Clin Ophthalmol. 2011; 5: 745-9. http://dx.doi.org/10.2147/OPTH.S19279

[49] EUROPEAN MEDICINES AGENCY, EDITOR. LUCENTIS PRODUCT INFORMATION.

[50] MOJA L, LUCENTEFORTE E, KWAG KH, BERTELE V, CAMPOMORI A et al. Systemic safety of bevacizumab versus ranibizumab for neovascular age-related macular degeneration. Cochrane Database Syst Rev. 2014; 9: CD011230. http:// dx.doi.org/10.1002/14651858.cd011230

[51] MOSHFEGHI AA, ROSENFELD PJ, PULIAFITO CA, MICHELS S, MARCUS EN et al. Systemic bevacizumab (Avastin) therapy for neovascular age-related macular degeneration: twenty-four-week results of an uncontrolled open-label clinical study. Ophthalmology. 2006; 113: 2002.e1-12.

[52] FIELDEN M, NELSON B, KHERANI A. Acute intraocular inflammation following intravitreal injection of bevacizumab-a large cluster of cases. Acta Ophthalmol. 2011; 89: e664-5. http://dx.doi.org/10.1111/j.1755-3768.2010.02054.x

[53] GEORGOPOULOS M, POLAK K, PRAGER F, PRUNTE C, SCHMIDT-ERFURTH U. Characteristics of severe intraocular inflammation following intravitreal injection of bevacizumab (Avastin). Br J Ophthalmol. 2009; 93: 457-62. http://dx.doi.org/10.1136/bjo.2008.138479

[54] PENHA FM, RODRIGUES EB, MAIA M, FURLANI BA, REGATIERI $C$ et al. Retinal and ocular toxicity in ocular application of drugs and chemicals-part II: retinal toxicity of current and new drugs. Ophthalmic Res. 2010; 44: 205-24. http://dx.doi.org/10.1159/000316695

[55] DARLOW BA, ELLS AL, GILBERT CE, GOLE GA, QUINN GE. Are we there yet? Bevacizumab therapy for retinopathy of prematurity. Arch. Dis. Child. Fetal Neonatal Ed. 2013; 98: F170-4. http://dx.doi.org/10.1136/archdischild-2011-301148

[56] MICHELS S, ROSENFELD PJ, PULIAFITO CA, MARCUS EN, VENKATRAMAN AS. Systemic bevacizumab (Avastin) 
therapy for neovascular age-related macular degeneration twelve-week results of an uncontrolled open-label clinical study. Ophthalmology. 2005; 112: 1035-47. http://dx.doi. org/10.1016/j.ophtha.2005.02.007

[57] SCHMID-KUBISTA KE, KREBS I, GRUENBERGER B, ZEILER F, SCHUELLER J et al. Systemic bevacizumab (Avastin) therapy for exudative neovascular age-related macular degeneration. The BEAT-AMD-Study. Br J Ophthalmol. 2009; 93: 914-9. http://dx.doi.org/10.1136/ bjo. 2008.144410

[58] SCHOUTEN JSAG, LA HEIJ EC, WEBERS CAB, LUNDQVIST IJ, HENDRIKSE F. A systematic review on the effect of bevacizumab in exudative age-related macular degeneration. Graefes Arch. Clin. Exp. Ophthalmol. 2009; 247: 1-11. http://dx.doi.org/10.1007/s00417-008-0952-y

[59] KERNT M, NEUBAUER AS, LIEGL RG, HIRNEISS C, ALGE CS et al. Sorafenib prevents human retinal pigment epithelium cells from light-induced overexpression of VEGF,
PDGF and PlGF. Br J Ophthalmol. 2010; 94: 1533-9. http:// dx.doi.org/10.1136/bjo.2010.182162

[60] TIAN L-L, REN B, GAO X-W, LUO Y, CAI Y et al. Inhibition of retinopathy of prematurity in rat by intravitreal injection of sorafenib. Int J Ophthalmol. 2014; 7: 198-204.

[61] KANG S, ROH CR, CHO W-K, PARK KC, YANG K-J et al. Antiangiogenic effects of axitinib, an inhibitor of vascular endothelial growth factor receptor tyrosine kinase, on laser-induced choroidal neovascularization in mice. Curr. Eye Res. 2013; 38: 119-27. http://dx.doi.org/10.3109/02713683.2012.727520

[62] TSUBOTA K. Tear dynamics and dry eye. Prog Retin Eye Res. 1998; 17: 565-96. http://dx.doi.org/10.1016/S13509462(98)00004-4

[63] HUSSAIN M, SHTEIN RM, SUGAR A, SOONG HK, WOODWARD MA et al. Long-term use of autologous serum $50 \%$ eye drops for the treatment of dry eye disease. Cornea. 2014; 33: 1245-51. http://dx.doi.org/10.1097/ ICO.0000000000000271 